Linguista: Jurnal Ilmiah Bahasa, Sastra, dan Pembelajarannya

Vol.3, No.2, Desember 2019, hal 91-104

ISSN (print): 2579-8944; ISSN (online): 2579-9037

Avaliable online at: http://e-journal.unipma.ac.id/index.php/linguista

\title{
Peningkatan Kemampuan Menulis Tegak Bersambung dengan Menggunakan Pembelajaran Model Jigsaw melalui Buku Tulis Halus pada Siswa Kelas II SDN 02 Mojorejo Kota Madiun
}

\author{
Sayekti \\ SDN 02 Mojorejo, Jl. Abdurrahman Saleh No.1, Madiun, Indonesia \\ e-mail: sayekti68@gmail.com
}

\begin{abstract}
Abstrak
Penelitian ini bertujuan untuk peningkatkan prestasi belajar pada pembelajaran menulis tegak bersambung siswa kelas II SDN 02 Mojorejo. Mengingat bahwa siswa belum memahami menulis huruf tegak bersambung. Siswa belum memahami menulisbentuk huruf, ukuran huruf, tebal tipisnya penulisan huruf, tanda baca, serta kerapian dengan menggunakan huruf tegak bersambung. Penelitian mengambil subyek siswa kelas II SDN 02 Mojorejo Kota Madiun yang berjumlah 28. Siswa laki-laki berjumlah 16 orang dan siswa perempuan berjumlah 12 orang. Metode yang digunakan pada penelitian ini adalah Penelitian Tindakan Kelas (PTK). Pelaksanaan penelitian ini dilakukan secara kolaboratif antara peneliti dan guru dalam mengambil gambar (foto) sebagai dokumen. Dari penelitian yang dilakukandiperoleh hasil nilai rata-rata siswa pada kegiatan study awal sebesar 70,5 dengan persentase ketuntasan sebesar $46 \%$. Kondisi tersebut mengalami peningkatan nilai rata-rata siswa pada siklus 1 yaitu sebesar 80,25 dan persentase ketuntasan sebesar $82 \%$. Kemudian setelah melanjutkan ke siklus 2 nilai rata-rata siswa dalam pembelajaran menulis tegak bersambung kembali mengalami peningkatan sebesar 84 dengan persentase ketuntasan sebesar $96 \%$. Hal tersebut menunjukkan bahwa target yang telah ditetapkan sebelumnya sudah tercapai.
\end{abstract}

Kata kunci: Menulis Tegak Bersambung; Model Jigsaw, Buku Tulis Halus.

\section{Improving Continuous Vertical Writing Ability by Using Jigsaw Model Learning through Smooth Writing Books for the Second Grade Students of SDN 02 Mojorejo, Madiun City}

\begin{abstract}
This study aims to improve learning achievement in learning to write Continuous Vertical for the second grade students at SDN 02 Mojorejo. The students do not yet understand writing Continuous Vertical letters. Students do not understand how to write letters, font size, and the thickness of letter writing, punctuation, and neatness by using Continuous Vertical letters. The subject of the study was the second grade students of SDN 02 Mojorejo Madiun City, consisting of 28 people: 16 male and 12 female. The method used in this study is Classroom Action Research (CAR). This study aims to improve the ability to write Continuous Vertical for the second grade students. The research was carried out collaboratively between the researcher and teachers in taking pictures (photos) as documents. The results show, the average student score in the initial study activity was 70.5 with a percentage of completeness of $46 \%$. This condition has increased the average value of students in cycle 1 that is 80.25 and the percentage of completeness is $82 \%$. Then after continuing to cycle 2 the average value of students in learning to write Continuous Vertical again has increased by 84 with a percentage of completeness of 96\%. This shows that the predetermined target has been achieved.
\end{abstract}

Keywords: Continuous Vertical Writing; Jigsaw Learning model; Smooth Notebook. 


\section{Pendahuluan}

Aktivitas menulis merupakan suatu bentuk manifestasi kemampuan (keterampilan) berbahasa paling akhir dikuasai pelajar bahasa setelah kemampuan mendengarkan, berbicara, dan membaca menurut Nurgiantoro (2009: 296). Dibandingkan tiga berbahasa yang lain, kemampuan menulis lebih sulit dikuasai bahkan oleh penutur asli bahasa yang bersangkutan sekalipun. Hal itu disebabkan kemampuan menulis menghendaki penguasaan berbagai unsur kebahasaaan dan unsur luar bahasa itu sendiri yang akan menjadi isi karangan. Baik unsur bahasa maupun unsur isi haruslah terjalin sedemikian rupa sehingga menghasilkan karangan yang runtut dan padu.

Kemampuan menulis dijaman sekarang mempunyai peranan yang saangat penting. Sebagaimana pendapat Erlina (2015: 2) bahwa kehidupan yang serba maju ini, kemampuan menulis mempunyai peran yang semakin besar. Hampir setiap segi kehidupan memerlukan kemampuan menulis. Menulis sangat penting bagi pendidikan karena memudahkan para siswa untuk berpikir, dapat menolong kita berpikir secara kritis, memudahkan kita merasakan mengajak siswa berlatih memahami dan menggunakan bahasa, terutama di SD. Pemahaman seperti ini, guru akan terdorong untuk merancang dan melaksanakan kegiatan pembelajaran membaca, menulis, menyimak, dan berbicara dengan lebih bervariasi lagi sehingga pengalaman belajar dari kegiatan pembelajaran ini tambah bermakna bagi siswa.

Pengertian kemampuan menulis menurut pendapat Setiyaningsih sebagai berikut. Setiyaningsih (2013: 13) kemampuan adalah kecakapan seseorang untuk melakukan suatu tugas yang dikuasainya melalui praktik atau latihan. Pengertian menulis adalah suatu kegiatan berkomunikasi atau menyampaikan gagasan, pikiran, dan ide ke dalam bentuk tulisan. Jadi kemampuan menulis adalah kecakapan atau kesanggupan seseorang dalam menghasilkan suatu tulisan berdasarkan gagasan, pikiran, dan ide yang dimilikinya.

Kesulitan dalam melakukan integrasi sensori tersebut dapat menimbulkan berbagai masalah atau kekurangan dalam menulis tegak bersambung. Masalah atau kekurangan dalam menulis tegak bersambung yang ada pada masing-masing siswa berbeda satu sama lain. Beberapa diantaranya dapat ditemukan pada tulisan siswa. Secara umum tulisan siswa SD kelas awal masih banyak memiliki kekurangan, misalnya tulisan siswa masih: (1) kurang rapi, (2) belum jelas keterbacaannya, (3) putus-putus, dan (4) keluar garis buku. Contoh hasil dokumentasi pembelajaran menulis tegak bersambung siswa tersaji pada lampiran 1, menurut pendapat Setiyaningsih (2013: 5).

Berdasarkan uraian di atas peneliti berpendapat bahwa menulis termasuk kempetensi/kemampuan keterampilan. Keterampilan menulis tegak bersambung diajarkan kelas awal seperti kelas I, II, dan kelas III. Walaupun jaman sudah maju (zaman now) pembelajaraan menulis tegak bersambung tetap diajarkan karena untuk melatih motori halus siswa.

Berdasarkan hasil observasi terhadap siswa kelas II yang dilakukan di SD Negeri 02 Mojorejo Kota Madiun diperoleh data sebagai berikut: (1) Siswa belum memahami bentuk huruf tegak bersambung. (2)Siswa belum memahami ukuran huruf tegak bersambung. (3) Siswa belum memahami tebal tipisnya penulisan huruf tegak bersambung. (4) Siswa belum memahami tanda baca. (5) Siswa belum memahami 
kerapian tulisan huruf tegak bersambung. Berdasarkan permasalahan yang sudah diuraian diatas, siswa belum mampu menulis huruf tegak bersambung tegak bersambung yang berpengaruh terhadap rendahnya hasil belajar siswa menulis huruf tegak bersambung, yaitu memperoleh nilai di bawah KKM (75). Maka dari itu peneliti ingin meningkatkan kemampuan menulis tegak bersambung menggunakan model pembelajaran jigsaw melalui buku tulis pada siswa kelas II SDN 02 Mojorejo Kota Madiun.

\section{Metode Penelitian}

Pendekatan yang digunakan dalam penelitian ini adalah pendekatan Penelitian Tidakan Kelas (PTK). Penelitian ini dilakukan secara kolaboratif, antara guru dan peneliti. Peneliti bekerja sama dengan guru dan siswa dalam melakukan penelitian tindakan kelas ini. Dalam penelitian tindakan kelas ini, penulis mengumpulkan data melalui teknik dokumentasi, obsevasi dan tes. Pengertian teknik dokumentasi, menurut Sugiyono (2013:240) dokumen merupakan catatan peristiwa yang sudah berlalu. Dokumen bisa berbentuk tulisan, gambar, atau karya-karya monumental dari seorang. Dokumen yang berbentuk tulisan misalnya catatan harian, sejarah kehidupan (life histories), ceritera, biografi, peraturan, kebijakan. Dokumen yang berbentuk gambar misalnya foto, gambar hidup, sketsa dan lain-lain. Dokumen yang berbentuk karya misalnya karya seni, yang dapat berupa gambar, patung, film dan lain-lain. Studi dokumen merupakan pelengkap dari penggunaan metode observasi dan wawancara dalam penelitian kualitatif.

Model yang digunakan dalam penelitian ini adalah model Kemmis dan Mc Taggart. Model ini dipilih karena hasil penelitian dengan menggunakan model ini dapat digunakan sebagai bahan pertimbangan untuk memperbaiki dan menyempurnakan pembelajaran menulis tegak bersambung di SD Negeri 02 Mojorejo Kota Madiun. Penelitiandilakukan meliputi perencanaan, kemudian melaksanakan tindakan dan pengamatan, selanjutnya refleksi, dan rencana perbaikan. Apabila pada siklus I belum berhasil maka diadakan upaya perbaikan pada siklus II, dan seterusnya.
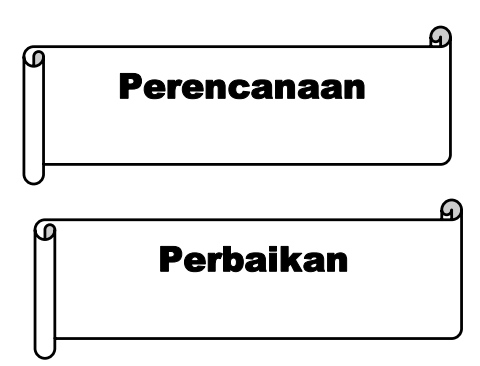

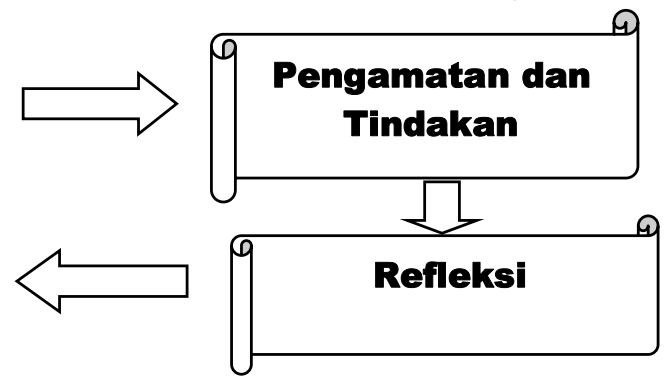

Gambar 1. Alur Penelitian

Pelaksanaan siklus yang digunakan dalam penelitian ini disesuaikan dengan hasil yang diperoleh pada pengamatan sebelumnya. Siklus 1 terdiri dari langkah-langkah perencanaan, tindakan dan observasi, serta refleksi. Kegiatan pada siklus 1 apabila belum mencapai tujuan akan dilanjutkan dengan perencanaan siklus 2. Apabila siklus 2 tujuan pembelajaran belum tercapai maka akan dilanjutkan pada perencanaan siklus ke 3, dst.

Peneliti menggunakan analisis data kuantitatif untuk mengolah informasi yang bersifat observasi dan hasil tes. Dalam menganalisis data kuantitatif diperoleh dari data 
hasil observasi yang dilakukan terhadap siswa data hasil tes pratindakan dan hasil tes di akhir setiap siklus pada pembelajaran menulis tegak bersambung. Data yang didapatkan ditampilkan dalam bentuk angka. Untuk menghitung hasil observasi selama proses pembelajaran menulis huruf tegak bersambung mengacu pada penskoran skala Likert dan skala Guttman menurut Sugiyono (2009: 96-97).

Tabel 1. Penskoran Hasil Observasi dengan Skala Guttman

\begin{tabular}{llcc}
\hline No. & & Jawaban & Skor \\
\hline 1. & Ya & 1 \\
\hline 2. & Tidak & 0 \\
\hline
\end{tabular}

Keterangan:

Ya : guru melaksanakan pembelajaran sesuai dengan aspek-aspek penilaian dan siswa mampu melaksanakan semua aspek penilaian.

Tidak: guru tidak melaksanakan pembelajaran sesuai dengan aspek-aspek penilaian dan siswa tidak mampu melaksanakan semua aspek penilaian.

Tabel 2. Penskoran Hasil Observasi dengan Skala Likert

\begin{tabular}{ccc}
\hline No. & Jawaban & Skor \\
\hline 1. & Sangat kurang & 1 \\
\hline 2. & Kurang & 2 \\
\hline 3. & Cukup & 3 \\
\hline 4. & Baik & 4 \\
\hline 5. & Baik sekali & 5 \\
\hline
\end{tabular}

Keterangan:

1. Sangat kurang bernilai skor 1 . Skor 1 diberikan jika kegiatan yang diamati dilakukan oleh 0-20\% dari keseluruhan siswa atau 1-4 siswa.

2. Kurang bernilai skor 2 . Skor 2 diberikan jika kegiatan yang diamati dilakukan oleh 21-40\% dari keseluruhan siswa atau 5-8 siswa.

3. Cukup bernilai skor 3 . Skor 3 diberikan jika kegiatan yang diamati dilakukan oleh 41-60\% dari keseluruhan siswa atau 9-12 siswa.

4. Baik bernilai skor 4 . Skor 4 diberikan jika kegiatan yang diamati dilakukan oleh $61-80 \%$ dari keseluruhan siswa atau 13-16 siswa.

5. Baik sekali bernilai skor 5 . Skor 5 diberikan jika kegiatan yang diamati dilakukan oleh $81-100 \%$ dari keseluruhan siswa atau 17-20 siswa.

Peneliti menggunakan pedoman penilaianmenulis tegak bersambung menurut pendapat dari Ahmad Rofi'uddin dan Zuchdi. Adapun aspek yang dinilai yaitu (1) bentuk huruf (2) ukuran huruf (3) tebal tipisnya penulisan huruf (4) tanda baca (5) kerapihan. Jadi pedoman penilaian menulis tegak bersambung yang akan peneliti gunakan sebagaimana yang diuraikan berikut ini pada tabel 4 . 
Tabel 3. Pedoman Kemampuan Menulis Tegak Bersambung

\begin{tabular}{ccc}
\hline No & Aspek yang dinilai & Rentang Nilai \\
\hline 1 & Bentuk huruf & 30 \\
\hline 2 & Ukuran huruf & 15 \\
\hline 3 & Tebal tipisnya penulisan huruf & 15 \\
\hline 4 & Tanda baca & 15 \\
\hline 5 & Kerapian & 25 \\
\hline & Jumlah & 100 \\
\hline
\end{tabular}

Berdasarkan informasi yang diperoleh dan hasil obeservasi, serta data hasil kemampuan menulis huruf tegak bersambung diperoleh keterangan bahwa dari siswa II SDN 02 Mojorejo Kota Madiun sebagai berikut. (1) Pemahaman siswa tentang bentuk huruf menulis tegak bersambung masih kurang. (2)Pemahamansiswa tentang ukuran huruf menulis tegak bersambung masih kurang. (3) pemahaman siswa tentang tebal tipisnya menulis tegak bersambung. (4) Siswa masih kesulitan membuat kalimat dengan menggunakan huruf tegak bersambung. Peneliti dalam pembelajaran sebelumnya menggunakan metode ceramah dengan memberi contoh menulis tegak bersambung di papan, sehingga pembelajaran tersebut belum menarik. Kurangnya variasi model pembelajaran dalam pembelajaran menulis tegak bersambung akan berakibat pada kebosanan siswa, walaupun metode yang digunakan guru disertai contoh dalam menjelaskan di papan tulis.

Berdasarkan permasalahan tersebut peneliti memilih menggunakan model pembelajaran (pendekatan) kooperatif yaitu model jigsaw melalui buku halus, agar kemampuan menulis tegak bersambung siswa menjadi lebih baik (meningkat). Caranya: (1) Pembentukan kelompok awal, jumlah kelas II ada 28 siswa, maka kelompok awal terdiri dari 4 kelompok, masing-masing kelompok terdiri dari 7 siswa, (2) Tiap siswa dari kelompok asal mengerjakan tugas menulis huruf tegak bersambung (3) no urut dada I yang terdiri 7 anak mengerjakan tugas 1 , menuis menulis huruf tagak bersambung , (4) no urut dada ke II yang terdiri 7 anak mengerjakan tugas 2 menggunakan huruf tegak bersambung, (5) no urut dada ke III yang terdiri 7 anak mengerjakan tugas tugas 3 menggunakan huruf tegak bersambung, (6) no urut dada ke IV yang terdiri dari 7 anak mengerjakan tugas 4 menggunakan huruf tegak bersambung, (7) Anggota kelompok lain bertemu dalam kelompok baru (keompok ahli) untuk mendiskusikan tugas yang sudah diberikan. Kelompok ahli berdiskusi mengerjakan tugas yang sudah diberikan, (8) setelah selesai diskusi, tim ahli kembali ke kelompok asal, (9) Kelompok asal mengerjakan tugas, seteah selesai masing-masing kelompok awal mempresentasikan hasil tugas yang sudah dikerjakan, (10) Guru sebagai fasilitator dan memberikan evaluasi.

\section{Hasil dan Pembahasan}

\section{Hasil}

Pelaksanaan penelitian tindakan kelas ini berlangsung dalam dua siklus. Dua kali pertemuan pada siklus 1 dan siklus 2 . Siklus 1 berlangsung dari tanggal 24 dan 25 September 2018. Penelitian tindakan kelas ini meliputi empat tahapan penelitian, yaitu: (a) perencanaan, (b) tindakan, (c) observasi, dan (d) refleksi. Keempat tahapan tersebut dilaksanakan pada setiap siklus. Berikut penjelasan dari masing-masing siklus, adapun uraiannya sebagai berikut. Pada tahap perencanaan, peneliti melakukan refleksi 
terhadap praktik menulis tegak bersambung pada pembelajaran Bahasa Indonesia pada siswa kelas II. Peneliti melakukan wawancara tentang permasalahan yang dialami siswa selama mengikuti pembelajaran menulis tegak bersambung. Peneliti menyiapkan lembar observasi untuk siswa dan guru. Peneliti menyusun pedoman penilaian menulis tegak bersambung. Peneliti menyiapkan instrumenpenilaian/alat penilaian yang berupa soal-soal yang berkaitan dengan menukis huruf tegak bersambung. Peneliti mempersiapkan sumber dan materi pembelajaran menulis tegak bersambung.

Pelaksanaan Tindakan Observasipeneliti melaksanakan pembelajaran menulis tegak bersambung mengacu pada Pelaksanaan Pembelajaran (RPP) yang sudah dibuat oleh peneliti. Adapun langkah-langkahnya meliputi kegiatan awal, kegiatan inti, dan penutup. Pada kegiatan awal peneliti mengkondisikan siswa untuk melakulan doa, literasi dan apersepsi. Kegiatan inti guru dan siswa mengkondisikan proses pembelajaran menulis tegak bersambung dengan menggunakan model pembelajaran jigsaw. Kegiatan penutup guru dan siswa melakukan kesimpulan tentang materi yang sudah dilaksanakan.

Observasi atau pengamatan dilakukan untuk mengamati proses pembelajaran menulis tegak bersambung. Observasi dilakukan untuk merekam proses yang terjadi selama pembelajaran menulis tegak bersambung berlangsung. Tujuan observasi dalam kegiatan penelitian ini adalah untuk mengamati proses pembelajaran menulis tegak bersambung di SD Negeri 02 Mojorejo. Observasi ini difokuskan pada kegiatan guru dan siswa selama berlangsungnya pembelajaran menulis tegak bersambung. Refleksi merupakan suatu kegiatan pemberian makna dan pemahaman terhadap proses dan hasil belajar yang terjadi pada siklus 1 . Hasil interpretasi tersebut, jika belum memenuhi tujuan penelitian maka perlu dilakukan langkah-langkah perbaikan pada siklus selanjutnya. Penelitian ini dikatakan berhasil jika tujuan penelitian yang sudah ditetapkan tercapai.

Nilai hasil tes menulis tegak bersambung siswa kelas II pada kegiatan studi awal dan siklus I dibuat diagram batang. Adapun diagram batang nilai hasil tes studi awal dan siklus I menulis tegak bersambung tersaji pada gambar 2 .

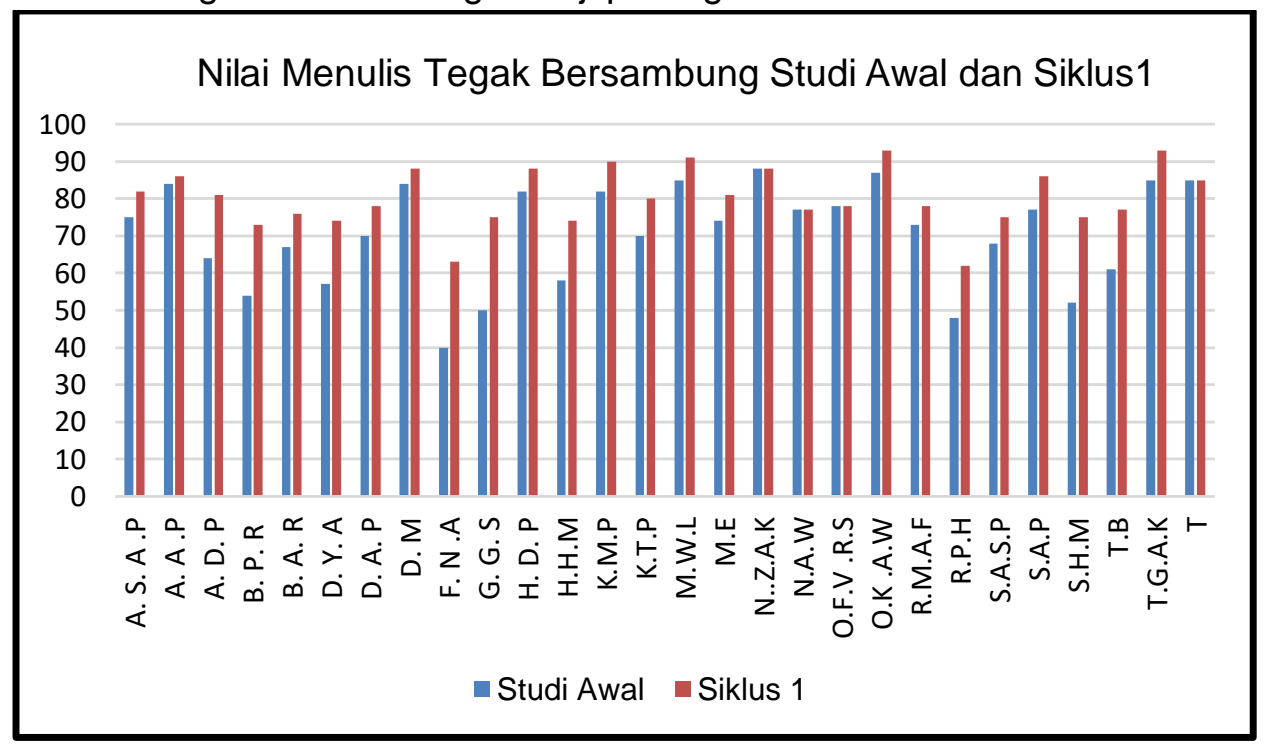

Linguista Vol. 3, No. 2, Desember 2019: 91-104 
Gambar 2. Diagram Batang Nilai Menulis Tegak Bersambung Siswa pada Kegiatan Studi Awal dan Siklus 1.

Berdasarkan gambar 2 data nilai tes menulis tegak bersambung dengan menggunakan model jigsaw pada siklus I diperoleh data sebagai berikut. Nilai rata-rata yang diperoleh sebesar 80,25. Siswa yang nilainya mencapai KKM ada 23 anak (82\%). Siswa yang belum mencapai KKM ada 5 anak (18\%).

Pada siklus 1 terdapat beberapa temuan pada niai hasil tes menulis huruf tegak bersambung. Adapun temuannya sebagaimana diuraikan dibawah ini. Ada beberapa siswa yang masih belum belum mencapai KKM karena (1) Siswa belum memahami bentuk huruf tegak bersambung. (2) Siswa belum memahami ukuran huruf tegak bersambung. (3) Siswa belum memahami tebal tipisnya penulisan huruf tegak bersambung. (4) Siswa belum memahami tanda baca. (5) Siswa belum memahami kerapian tulisan huruf tegak bersambung.Berdasarkan data yang diperoleh dari nilai hasil tes menulis huruf tegak bersambung tersebut maka peneliti bermaksud untuk memperbaiki, meningkatkan, dan memaksimalkan kemampuan siswa dalam menulis tegak bersambung melalui model pembelajaran jigsaw pada tindakan siklus II.

Berdasarkan hasil observasi guru selama proses pembelajaran pada siklus I diketahui bahwa kegiatan guru dalam proses pembelajaran menulis tegak bersambung sudah berlangsung baik dengan persentase $82 \%$. Pada hasil pengamatan di atas ada beberapa temuandiantaranya guru tidak mengintruksikan pada kelompok asal untuk mempresentasikan hasil kerja kelompoknya dan guru tidak memberikan penguatan. Pernyataan tersebut benar guru belum melakukan hal tersebut karena waktunya sudah selesai. Guru di awal pembelajaran banyak menjelaskan tentang alur skenario pembelajaran model jigsaw tersebut. Sedangkan siswa sendiri baru mengenal model pembelajaran tersebut. Oleh sebab itu poin tersebut belum terlaksana dengan baik.

Berdasarkan hasil observasi siswa selama proses pembelajaran pada siklus I diketahui bahwa kegiatan siswa dalam proses pembelajaran menulis tegak bersambung sudah berlangsung baik dengan persentase $73 \%$. Pada hasil pengamatan di atas ada beberapa temuan sebagai berikut. Sedangkan temuannya adalah belum mengerjakan soal tugas pada kelompok asal. Maksud dari pernyataan tersebut adalah ada beberapa siswa yang masih belum paham pada teman kelompoknya. Temuan yang kedua siswa belum mempresentasikan hasil kerja kelompoknya. Maksudnya pernyataan tersebut adalah karena waktunya sudah selesai jadi belum sempat mempresentasikan hasil kerja kelompok asal. Temuan yang ketiga siswa belum menerima penguatan dengan lapang dada saat terjadi kesalah pahaman dikelompoknya. Maksud dari pernyataan tersebut adalah karena waktu yang tidak mencukupi akhirnya siswa belum menerima penguatan dari guru.

Setelah dalam proses pembelajaran menulis huruf tegak bersambung menggunakan model pembelajaran jigsaw dengan maksimal maka diperoleh peningkatan nilai yang signifikan. Siswa yang mencapai KKM sebagian besar karena (1) Siswa sudah memahami menulis huruf tegak bersambung. (2)Siswa merasa tidak kesulitan menulis huruf kapital di awal kalimat dengan menggunakan huruf tegak bersambung. (3) Siswa selalu ingat menulis nama orang dan nama tempat/kota dengan huruf kapital menggunakan huruf tegak bersambung. (4) Siswa tidak kesulitan lagi membuat kalimat dengan menggunakan huruf tegak bersambung. 
Terbukti pada data tabel siklus 2 diatas maka diperoleh nilai hasil tes menulis huruf tegak bersambung kelas II SDN 02 Mojorejo sebagai berikut. Nilai rata-rata yang diperoleh sebesar 84. Siswa yang nilainya mencapai KKM ada 27 anak (96\%). Siswa yang belum mencapai KKM ada 1 anak (4\%). Setelah proses pembelajaran siklus 2 maka peneliti akan mambuat diagram batang. Diagram batang tersebut dari data nilai hasil tes menulis huruf tegak bersambung pada studi awal, siklus 1, dan siklus 2 mengalami peningkatan. Adapun gambarnya terdapat pada gambar 3 di bawah ini.

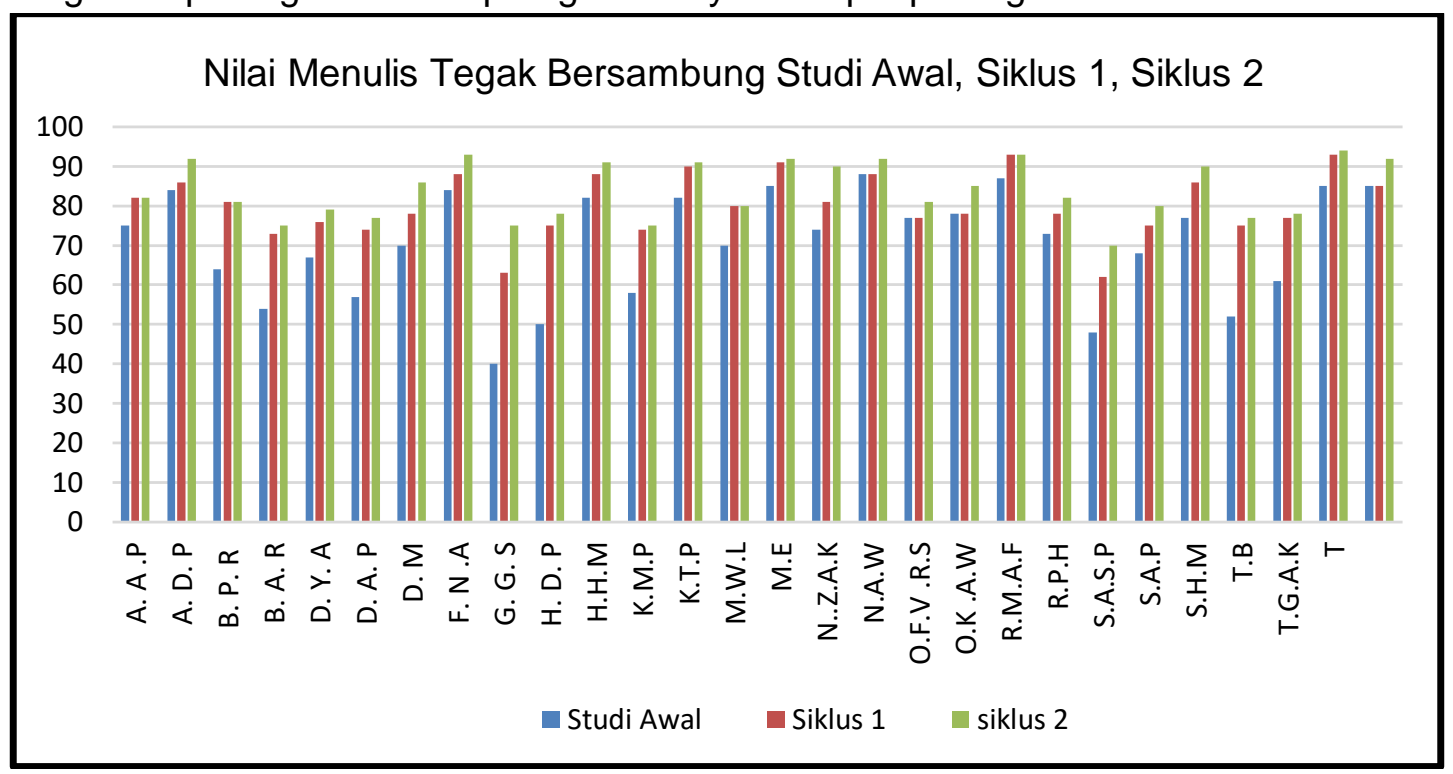

Gambar 3. Diagram Batang Nilai Menulis Tegak Bersambung Siswa pada Kegiatan Studi Awal, Siklus 1, dan Siklus 2

Berdasarkan gambar diagram batang nilai menulis tegak bersambung diatas, secara umum mengalami peningkatan. Data nilai hasil tes menulis huruf tegak bersambung berangsur-angsur naik dari studi awal, ke siklus 1 dan siklus 2 . Nilainya dari masing-masing siswa kelas II SDN 02 Mojorejo semua juga menalami peningkatan. Berdasarkan pengamatan selama proses pembelajaran pada siklus 2 diketahui bahwa kegiatan guru dan siswa dalam mengikuti pembelajaran menulis tegak bersambung sudah berlangsung sangat baik dengan persentase 100\%. Pada hasil pengamatan di atas secara umum proses pembelajaran menulis huruf tegak bersambung pada siswa kelas II SDN 02 mojorejo sudah tidak ada kendala yang berarti. Hal ini dikarenakan pada proses pembelajaran menulis huruf tegak bersambung menggunakan model jigsaw secara maksimal sehingga dapat meningkatkan konsentrasi siswa.

Berdasarkan pengamatan guru, yang terdapat pada tabel 4.5 menunjukkan bahwa pembelajaran menulis tegak bersambung pada siswa kelas II SDN 02 Mojorejo dengan menggunkan model jigsaw pada siklus 2 mengalami peningkatan. Hal ini terbukti bahwa sebagian besar siswa sudah memahami beberapa kriteri menulis huruf tegak bersambung sebagai berikut. (1) Siswa sudah memahami bentuk huruf tegak bersambung. (2)Siswa sudah memahami ukuran huruf tegak bersambung. (3) Siswa sudah memahami tebal tipisnya penulisan huruf tegak bersambung. (4) Siswa sudah memahami tanda baca. (5) Siswa sudah memahami kerapian tulisan huruf tegak bersambung. Data peningkatan nilai tes menulis tegak bersambung kelas II SDN 02 
Mojorejo darikegiatan studi awal, siklus 1, dan siklus 2. Peningkatan hasil tes menulis tegak bersambung tersebut tersaji pada tabel 4 .

Tabel 4. Peningkatan Hasil Tes Studi Awal, Siklus 1, dan Siklus 2

\begin{tabular}{llccc}
\hline No. & \multicolumn{1}{c}{ Aspek } & Studi awal & Siklus 1 & Siklus 2 \\
\hline 1. & Jumlah nilai & 1.975 & 2.247 & 2.351 \\
\hline 2. & Nilai rata-rata & 70.5 & 80.25 & 84 \\
\hline 3. & Persentaseketuntasan & $46 \%$ & $82 \%$ & $96 \%$ \\
\hline
\end{tabular}

Berdasarkan tabel datas jumlah nilai pada studi awal 1.975, nilai rata-rata 70.5 dan prosentase ketuntasannya 46\%. Pada siklus 1 hasil tesnya meningkat dengan jumlaj nilai 2.247 , nilai rata-rata 80.25 , dan prosentase ketuntasannya $82 \%$. Pada siklus 2 terjadi peningkatan yang signifikan jumlah nilai 2.352. nilai rata-rata 84 , dan prosentase ketuntasannya $96 \%$. Jadi peneliti menyimpulkan bahwa dengan melaksanakan proses pembelajaran dengan menggunakan model pembelajaran jigsaw maka hasil tes menulis tegak bersambung dapat meningkat secara signifikan.

Tabel 5. Peningkatan Hasil Observasi Guru dan Siswa Siklus 1, dan Siklus 2

\begin{tabular}{llcccc}
\hline \multirow{2}{*}{ No. } & \multirow{2}{*}{ Aspek } & \multicolumn{2}{c}{ Siklus 1 } & \multicolumn{2}{c}{ Siklus 2 } \\
\cline { 3 - 6 } & Guru & Siswa & Guru & Siswa \\
\hline \multirow{2}{*}{ 1. } & Persentase ketuntasan & $82 \%$ & $73 \%$ & $100 \%$ & $100 \%$
\end{tabular}

Berdasarkan data tabel 5 di atas bahwa saat observasi guru dan siswa pada proses pembelajaran menulis tegak bersambung mengalami peningkatan. Hal ini terbukti yang semula observasi guru pada siklus 1 persentase ketuntasannya $82 \%$, meningkat pada siklus 2 menjadi persentase ketuntasannya $100 \%$. Dan observasi pada siswa semula pada siklus 1 mencapai $73 \%$ pada siklus II menjadi $100 \%$. Peneliti mengamati pada siklus 1 siswa masih belum memahami pembelajaran dengan menggunakan model pembelajaran jigsaw. Pada siklus 2 siswa sudah memahami pembelajaran dengan menggunakan model jigsaw. Oleh sebab itu dengan peningkatan pemahaman siswa terhadap model pembelajaran jigsaw maka akan berpengaruh pula pada peningkatan hasil tes menulis tegak bersambung.

\section{Pembahasan}

Kemampuan menulis tegak bersambung siswa kelas II SDN 02 Mojorejo kota Madiun melalui model pembelajaran jigsaw. Peneliti akan memaparkan tentang peningkatanhasil nilai tes menulis tegak bersambung pada studi awal, siklus 1, dan siklus 2. Berdasarkan hasil belajar siswa menulis huruf tegak bersambung siswa kelas II SDN 02 Mojorejo mulai dari studi awal, ke siklus 1, dan siklus 2 mengalami peningkatan.Kemampuan siswa dalam menulis tegak bersambung didasarkan ataslima aspek penilaian menulis tegak bersambung. Kelima aspek tersebut adalah (a) bentuk huruf tegak bersambung. (b) ukuran huruf tegak bersambung. (c) tebal tipisnya penulisan huruf tegak bersambung. (d) tanda baca. (e) kerapian tulisan huruf tegak bersambung.Berikutini merupakan pemaparan dari setiap aspek.

a. Bentuk huruf

Hasil tulisan siswa dalam penelitian ini harus sesuai dengan ukuran huruf. Pada kegiatan studi awal sebagian besar siswa masih belum memahami bentuk huruf tegak bersambung. Sebagian besarmasih sulit untuk membedakan bentuk huruf $b, h$, k, dan I.Penulisan huruf $b, h, k$,dan I yangbenar melengkung keatas yang panjangnya sampai tiga garis. Penulisan huruf $t$, dan d panjangnya dua garis dan tidak melengkung. Siswa- 
siswa tersebut masih menuliskan bentuk huruf $b, h, k$, dan Isebagian besar tingginya ke atas masih dua baris keatas dan penulisan $t$, dan $d$ tingginya dua baris dan melengkung. Contohnya adalah hasil tulisan siswa, BPR, BAR,DM, DAP, FNA, GGS, HDP, KTP,ME, NAW, RMAF, RPH, SASP, TB dan SHM.

Berdasarkan hasil menulis tegak bersambung pada siklus 1 sudah mengalami peningkatan, masihada beberapa siswa yang penulisannya $b, h, k$, I dan penulisannya $\mathrm{d}, \mathrm{t}, \mathrm{s}$ masih belum sesuai aturan yaituBPR, DYA, FNA, HHM, RPH. Siswa-siswa tersebut masihmerangkai huruf $b, h$, k, dan I panjangnya garis melengkung keatasnya masih dua garis. Siswa-siswa yang penulisannya $d$ dan $t$ panjangnya dua garis dan melengkung.

Hasil menulis siswa pada siklus 2 sudah mulai mengalami peningkatan yang signifikan. Hal ini terbukti bahwa siswa yang tulisannya belum sesuai dengan bentuk huruf tinggal satu siswa yaitu RPHyang bentuk huruf tegak bersambungnya belum begitu jelas. Hasil tulisan siswa yang termasuk sedang yaitu FNA tulisannya sudah agak jelas. Sedangkan siswa yang termasuk kategori paling baik sudah meningkat yaitu AAP, DM, HDP, KMP, MWL, ME, NAW, OKAW, SAP, TGAK, dan T. Hasil tulisan RYmulai dari studi awal, siklus 1, siklus 2 masih sama dan tidak ada perubahan. Siswa RPH masih kesulitan dalam menulis tegak bersambung meskipun sudah diberikan latihan-latihan menulis. Berdasarkan hasil di atas yang menunjukkan peningkatan bentuk huruf kelas II SDN 02 mojorejo dalam menulis huruf tegak bersambung. Peneliti tidak sejalan dengan teori bentuk dan ukuran huruf di SD (Setiyaningsih, 2013:157) yaitu bentuk dan ukuran huruf hasil tulisan siswa dalam penelitian ini perlu sesuai dengan bentuk huruf tegak bersambung, ukuran hurufnya sedang dan dapat terbaca terlalu besar ukuran dan bentuk hurufnya dan ada pula yang terlalu kecil bentuk dan ukuran hurufnya.Menurut pendapat peneliti seharusnya disebutkan jenis hurufnya dan aturan panjang pendeknya huruf, jadi tidak hanya disebutkan bentuk hurufnya terlalu besar, terlalu kecil, dan sedang.

b. Ukuran huruf

Hasil tulisan menulis huruf tegak bersambung dalam penggunaan ukuran huruf pada studi awal ada separuh anak yang belum sesuai dengan ukuran huruf. Hampir separuh anak yang belum huruf diantaranya OFVRS, NAW, DM, RMAF, KMP, GGS, KTP, DM, BPR, FNA, HDP, BAR, TB, DYA, danASAP setelah peneliti menggunakan model pembelajaran jigsaw dan menggunkan buku tulis halus pada siklus 1 ada peningkatan dalam penulisan ukuran huruf sudah sesuai. Namun masih ada beberapa anak yang belum sesuai dengan ukuran huruf. Beberapa anak diantaranya KMP, GGS, KTP, DM, BPR, FNA, HDP, dan BAR. Pada siklus 2 peneliti menggunakan model pembelajaran jigsaw dengan maksimal maka diperoleh hasil yg signifikan. Pada dasarnya sebagian besar pada siklus 2 anak - anak sudahmenulisnya sudah sesuai dengan ukuran huruf tegak bersambung. Meskipun masih ada dua anak yang belum sesuai dengan ukuran pada saat menulis huruf tegak bersambung yaitu RPH dan GGS. c. Tebal tipisnya penulisan huruf tegak bersambung

Hasil menulis huruf tegak bersambung dalam penulisan tebal tipisnya huruf tegak bersambung pada studi awal ada separuh anak yang belum sesuai. Hampir separuh anak yang belum sesuai dengan tebal tipisnya diantaranya TGAK, AAP, NAW, DAP, RMAF, KMP, GGS, KTP, DM, BPR, FNA, HHDP, BAR, TB, DYA,RPH, FNA dan SAP. Setelah peneliti menggunakan model pembelajaran jigsaw dan menggunkan buku tulis 
halus pada siklus 1 ada peningkatan dalam tebal tipisnya penulisan huruh tegak bersambung. Namun masih ada beberapa anak belum memahami tebal tipisnya penulisan huruf tegak bersambung. Adapun nama anaknya sebagai berikut, GGS, KTP, DAP, BPR, FNA, HDP, dan BAR. Pada siklus 2 peneliti menggunakan model pembelajaran jigsaw dengan maksimal maka diperoleh hasil yg signifikan. Pada dasarnya sebagian besar pada siklus 2 anak - anak sudah memahami cara menulis tebal tipisnya $m$ huruf tegak bersambung. Meskipun masih ada dua anak yang belum memahami menulis dengan tebal tipisnya huruf tegak bersambung yaitu RPH dan GGS. d. Kerapian tulisan.

Kerapian penulisan merupakan aspek yang perlu dipenuhi dalam menulis tegak bersambung. Kerapian penulisan dapat dilihat dari hasil tulisan siswa.Kerapian menulis huruf tegak bersambung pada studi awal ada separuh anak yang belum rapi. Anak-anak yang belum rapi diantaranya TGAK, AAP, NAW, DM, RMAF, KMP, GGS, KTP, DAP, BAR, FNA, HHDP, BPR, TB, DYA, RPH, FNA dan SAP. Setelah peneliti menggunakan model pembelajaran jigsaw dan menggunkan buku tulis halus pada siklus 1 ada peningkatan kerapian dalam menulis huruf tegak bersambung. Namun masih ada beberapa anak dalam menulis huruf tegak bersambung belum rapi. Beberapa anak yang belum belum rapi dalam menulis huruf tegak bersambung diantaranya GGS, KTP, DAP, BAR, FNA, HHDP, dan BAR. Pada siklus 2 peneliti menggunakan model pembelajaran jigsaw dengan maksimal maka diperoleh hasil yg signifikan. Pada dasarnya sebagian besar pada siklus 2 anak - anak sudah rapi dalam menulis huruf tegak bersambung. Meskipun masih ada dua anak yang belum rapi dalam menulis huruf tegak bersambung yaitu RPH dan GGS. Berdasarkan data tersebut tentang kerapian penulisan tegak bersambung peneliti sejalan dengan pendapat Setiyaninsih (2013:172-174). Dalam penulisan huruf tegak bersambung aspek kerapiaan merupakan syarat yang harus dipenuhi dan dapat dilihat dari hasil tulisan. Sedangkan hasil tulisan siswa sebagian ada yang sudah rapi namun ada beberapa yang tulisannya sudah rapi.

e. Tanda Baca

Aspek penggunaan tanda baca menekankan pada penggunaan tanda titik di akhir kalimat pada setiap kalimat yang ditulis.Penggunaan tanda baca setelah menulis huruf tegak bersambung pada studi awal ada separuh anak yang belum menuliskan. Anak-anak yang belum rapi diantaranya TGAK, AAP, NAW, DM, RMAF, KMP, GGS, KTP, DAP, BAR, FNA, HHDP, BPR, TB, DYA, RPH, FNA dan SAP. Setelah peneliti menggunakan model pembelajaran jigsaw dan menggunkan buku tulis halus pada siklus 1 ada peningkatan dalam penggunaan tanda baca setelah menulis huruf tegak bersambung. Namun masih ada beberapa anak yang belum menulis tanda baca setelah menulis huruf tegak bersambung. Beberapa anak yang belum menggunakan tanda baca dalam menulis huruf tegak bersambung diantaranya GGS, KTP, DAP, BAR, FNA, HHDP, RPH dan BAR. Pada siklus 2 peneliti menggunakan model pembelajaran jigsaw dengan maksimal maka diperoleh hasil yg signifikan. Pada dasarnya sebagian besar pada siklus 2 anak - anak sudah menggunakan tanda baca dalam menulis huruf tegak bersambung. Meskipun masih ada dua anak yang belum rapi dalam menulis huruf tegak bersambung yaitu RPH dan GGS.

Berdasarkan hasil diatas tentang penggunaan tanda baca penulisan tegak bersambung peneliti sejalan dengan pendapat Setiyaninsih (2013:170). Dalam penulisan huruf tegak bersambung aspek penggunaan tanda baca sangat penting pada 
setiap selesai menulis kalimat. merupakan syarat yang harus dipenuhi dan dapat dilihat dari hasil tulisan. Sedangkan hasil tulisan siswa sebagian ada yang sudah rapi namun ada beberapa yang tulisannya belum rapi.

Berdasarkan hasil observasi siswa saat kegiatan pembelajaran menulis tegak bersambung pada studi awal, siklus 1, dan siklus 2 mengalami peningkatan. Proses pembelajaran yang dilakukan siswa juga sudah berlangsungdengan baik dan lancar. Persentase observasi kegiatan siswa pada siklus 1 sebesar $74 \%$.Pada siklus 1 siswa masih ada beberapa siswa yang belum konsentrasi pada pembelajaran menulis tegak bersambung sehingga hasil tesnya belum maksimal. Pada siklus 2 siswa-siswi sudah berpengalaman melakukan pembelajaran model jigsaw sehingga konsentrasinya meningkat. Prosentase observasi kegiatan siswa pada siklus 2 sebesar $96 \%$. Dengan meningkatnya konsentrasi siswa maka berpengaruh pada peningkatan hasil tes menulis tegak bersambung pada silkus 2 . Pada siklus 2 kegiatan pembelajaran terlihat aktif dan semangat ketika pembelajaran berlangsung. Namun, belum seluruh siswa yang terlihat aktif. Antusiasme siswa juga mulai terlihatketikasiswa diminta untuk menulis kalimat dengan menggunakan huruf tegak bersambung di buku tulis halus. Siswa terlihat sangat antusias dan semangat ketika diminta untuk membuat kalimat ajakan dengan kegiatan yang sudah mereka lakukan. Persentase kegiatan siswa juga mengalami peningkatan. Akan tetapi, masih ada satu siswa yang belum maksimal dalam menulis tegak bersambung. Persentase kegiatan siswa pada siklus 2 sebesar $96 \%$.

\section{Kesimpulan}

Peningkatan proses pembelajaran menulis tegak bersambung melalui model pembelajaran jigsaw pada siswa kelas II danSDN 02 Mojorejo kota Madiun ditandai dengan kegiatan pembelajaran yang lebih menarik, antusiasme dan semangat siswa lebih meningkat, konsentrasi dan perhatian siswa lebih terfokus, siswa lebih termotivasi dan semakin aktif dalam mengikuti pembelajaran menulistegak bersambung. Pada kegiatan pratindakan, siswa masih belum terlaluantusias dan semangat saat pembelajaran menulis tegak bersambung berlangsung.Guru dalam mengajar menulis tegak bersambung jugamasih terdapat beberapa kekurangan. Pada siklus 1, dan siklus

2 ,kegiatan siswa dan guru sudah terlihat semakin baik dan meningkat. Peningkatan hasil pembelajaran menulis tegak bersambung melalui model pembelajaran jigsaw pada siswa kelas II SDN02 Mojorejo kotaMadiun ditandai dengan peningkatan nilai rataratasiswa. Nilairata-rata siswa pada kegiatan study awal sebesar70,5 dengan persentase ketuntasan sebesar $46 \%$. Kondisi tersebut mengalami peningkatan nilairatarata siswa pada siklus 1 yaitu sebesar 80,25 dan persentase ketuntasan sebesar $82 \%$.Kemudian setelah melanjutkan ke siklus 2 nilai rata-rata siswa dalam pembelajaran menulis tegak bersambung kembali mengalami peningkatan sebesar 84 dengan persentase ketuntasan sebesar $96 \%$. Hal tersebut menunjukkan bahwa target yang telah ditetapkan sebelumnya sudah tercapai sehingga penelitian dihentikan pada siklus 2 .

\section{Daftar Pustaka}

Anas, S. (2011). Pengantar Evaluasi Pendidikan. Jakarta: Rajawali Pers.

Arikunto. (2010). Prosedur Penelitian. Jakarta: Rineka Cipta.

Burhan, N. (2009). Penilaian dalam Pengajaran Bahasa dan Sastra. Yogyakarta :BPFE. 
Dyah, T. P. (2016). Cara Mudah Memahami Kurikulum. Surabaya : Jaring Pena, Agustus 2016.

Depdiknas. (2009). Panduan untuk Guru Membaca dan Menulis Permulaan untuk Sekolah Dasar Kelas 1, 2, 3. Jakarta: Depdiknas.

Djuharie, O. S., dan Suherli, S. (2005). Panduan Membuat Karya Tulis. Bandung: Yrama Widya.

Hopkins, D. (2011). A Teacher's Guide to Classroom Research (Panduan Guru Penelitian Tindakan Kelas). Penerjemah: Ahmad Fawaid. Yogyakarta: Pustaka Pelajar.

Lembaga Pendidikan dan Pemberdayaan Potensi Masyarakat. (2010). Himpunan Peraturan Standart Nasional Pendidikan. Surabaya : Spek d'Trun. 2010.

Erlina, I. N. (2015). Peningkatan Hasil Belajar Menulis Tegak Bersambung Pada Mata Pelajaran Bahasa Indonesia Dengan Menggunakan Pendekatan Contextual Teaching And Learning Siswa Kelas 1B SD Sonosewu Kasihan Bantul Tahun Pelajaran 2014/2015. Universitas PGRI Yogyakarta.

Pontoh, H., Jamaludin, J., \& Hasdin, H. Penerapan Model Pembelajaran Jigsaw Untuk Meningkatkan Hasil Belajar Ilmu Pengetahuan Sosial (IPS) Siswa Kelas V SD Inpres Salabenda Kecamatan Bunta. Jurnal Kreatif Tadulako, 4(11).

Wondal, R., \& Djamrud, S. (2016). Penerapan Model Pembelajaran Kooperatif Tipe Jigsaw Untuk Meningkatkan Aktivitas Dan Hasil Belajar Ipa Pada Konsep Pencemaran Lingkungan. BIOEDUKASI, 3(1).

Budiawan, M. (2013). Pengaruh model pembelajaran kooperatif tipe jigsaw dan motivasi belajar terhadap prestasi belajar ilmu fisiologi olahraga. JPI (Jurnal Pendidikan Indonesia), 2(1).

Kementrian Pendidikan dan Kebudayaan Republik Indonesia. (2017). Buku Pedoman Guru Tema 5. Jakarta: 2017.

Kementrian Pendidikan dan Kebudayaan Republik Indonesia. (2017). Buku Siswa Tema 5. Jakarta: 2017.

Keputusan Direktorat Jenderal Pendidikan dan Menengah Departemen Pendidikan dan Kebudayaan No.094/C?Kepl./1,83, tanggal 7 Juli 1983. Penegasan Ukuran Tulisan Tangan No.0521/C2/U.88,27Juni1988).

Kurniawan, D. A. (2013). Mengajari Siswa atau Anak-Anak Menulis tegak bersambung. Makalah.

Ruafida, A. (2010). Peningkatan Keterampilan Menulis Permulaan Melalui Model Quantum Learning Pada Siswa Kelas 2 SD Negeri Karangasem 1 Laweyan Surakarta Tahun Pelajaran 2009/2010. Skripsi.

Sa'dun, A. (2012). Penelitian Tindakan Kelas dan Karya Ilmiah SD. Malang:25 April 2012

Sarwiji, S. (2011). Model Assesmen dalam Pembelajaran. Surakarta: Yuma Pustaka.

Sardiman. (2014). Interaksi dan Motivasi Belajar Mengajar. Jakarta: Rajawali Pers.

Setiyaningsih, F. (2013). Peningkatan Kemampuan Menullis Tegak Bersambung Melalui Model Pembelajaran Kontekstual Pada Siswa Kelas Aawal SD Negeri Karangputat 02 Cilacap. Skripsi. Universitas Negeri Yogyakarta. 
Shobibatur, R, (2016). Metode Picture and Picture untuk meningkatkan keterampilan menulis karangan sederhana kelas III Madrasah Ibtidaiyah Hasyim Asyari Sedati Sidoarjo. SKRIPSI.

Suryabrata, S. (2006). Psikologi Pendidikan. Jakarta: PT Raja Grafindo Persada. 